Bangladesh J. Plant Taxon. 28(1): 131-140, 2021 (June)

(C) 2021 Bangladesh Association of Plant Taxonomists

https://doi.org/10.3329/bjpt.v28i1.54213

\title{
A TAXONOMIC STUDY ON PTERIS L. (PTERIDACEAE) OF BANGLADESH
}

\author{
SHI-Yong Dong ${ }^{* 1}$ and A.K.M. Kamrul Haque ${ }^{2}$ \\ Key Laboratory of Plant Resources Conservation and Sustainable Utilization, South China
}

Keywords: Checklist; Misidentification; Morphology; Nomenclature; Taxonomy.

\begin{abstract}
Bangladesh lies in Indian subcontinent, an area rich in Pteris species. However, so far there is no modern account on the species diversity of Pteris in Bangladesh. Based on a thorough study of literature and limited specimens available to us, we currently recognize 15 species of Pteris in Bangladesh. Among these species, $P$. giasii is currently known only from Bangladesh; P. longipinnula, which has not been collected since 1858, was recently rediscovered in Sylhet. Pteris cretica, $P$. pellucida, P. quadriaurita var. $q u a d r i a u r i t a$, and $P$. quadriaurita var. setigera are excluded for the fern flora of Bangladesh. To facilitate the recognition of species, a key to species and brief notes for each species are provided.
\end{abstract}

\section{Introduction}

The genus Pteris L. (Pteridaceae) consists of about 250 species, being a natural group of terrestrial ferns across the world with relatively rich species in tropical, warm-temperate, and south-temperate areas (Tyron et al., 1990; PPG I, 2016). This group is well represented in East Asia with 85 species (Nakaike, 1982; Liao et al. 2013) and in Indian subcontinent with 57 species (Fraser-Jenkins et al., 2017). In comparison, other regions are not so rich with Pteris species. For example, there are 55 species in America (Tryon and Tryon, 1982), 39 in Indochina (Lindsay and Middleton, 2012; Phan, 2010), 24 in tropical Africa (Kamau, 2012), and only 10 in Australia (Kramer and McCarthy, 1998). Morphologically, the stable characters of Pteris include few, narrow scales restricted to rhizome and basal stipe, the marginal and linear sori, and the linear indusia formed by recurved, modified margin of lamina. Morphological variations between species lie mainly in leaf architecture (digitate, pinnate-pectinate, tripartite, etc.) and venation (from free, forming only costal areoles, to completely anastomosing) as shown in Tryon and Tryon (1982: 336-337). To date, no satisfactory subdivision of Pteris is available. Christensen (1906) divided Pteris into three subgenera, i.e., subg. Campteria with a row of costal areoles, subg. Litobrochia with amply reticulate veins, and subg. Eupteris with free veins. Ching and $\mathrm{Wu}$ (1983) proposed three sections, namely 1) sect. Pteris with free venation and non-pectinate pinnae, 2) sect. Quadriauricula Ching with free venation and pectinate pinnae, and 3) sect. Campteria (C. Presl) Ching with anastomosing venation. Tryon et al. (1990) suggested two subgenera (subg. Pteris and subg. Litobrochia) for the genus based mainly on the difference of venation. However, these are all entirely artificial, as Fraser-Jenkins et al. (2015: 305) commented, "in fact in S Asia there are no sections or subgenera within the genus". Recent molecular analyses based on plastid sequences supported Pteris to be a monophyletic group but did not support any subdivision previously proposed under this genus (Zhang et al., 2014). Species relationships within this large genus are still uncertain.

\footnotetext{
*Corresponding author, Email: dongshiyong@scib.ac.cn

${ }^{1}$ Botanical Garden, Chinese Academy of Sciences, Guangzhou 510650, China

${ }^{2}$ Department of Botany, Mohammadpur Govt. College, Dhaka, Bangladesh
} 
As compared with some countries in Indian subcontinent (such as India and Nepal), Pteris in Bangladesh is poorly documented. To know the species diversity of Pteris and other ferns in Bangladesh, currently the only literature to refer is Encyclopedia of Flora and Fauna of Bangladesh (Siddiqui et al., 2007). However, when consulting this book for the identification of a recent collection of Pteris from Sylhet, the first author (Dong) realizes the inaccuracy and incompletion of Pteris recorded in Siddiqui et al. (2007). Our new collection turns out to be $P$. longipinnula Wall. ex J. Agardh, a species which was collected in Sylhet probably early in 1850s (Hooker, 1858: 179) but was not included in Siddiqui et al. (2007). Other apparent deficiencies on the Pteris in Siddiqui et al. (2007) include the problematic spelling or misapplication of some species' names, such as "P. geminata Wall. apud Hook.", "P. longifolia var. vittata Roxb.", Pteris quadriaurita Retz., and Pteris quadriaurita var. setigera Bedd., which will be addressed in detail later in this account. In addition, Siddiqui et al. (2007) did not provide any taxonomic key to species or any critical description or list of key characters for the purpose of distinguishing species of similar morphology. Therefore, we conducted this study, aiming to provide accurate and updated knowledge on Pteris from Bangladesh in species recognition, nomenclature, and geographical distribution.

\section{Materials and Methods}

To update a checklist of Pteris from Bangladesh, we critically reviewed each names recorded in Siddiqui et al. (2007) according to the original descriptions, type specimens, and herbarium collections in JUH (Jahangirnagar University Herbarium), TAIF (Taiwan Forestry Research Institute), and US (Smithsonian Institution) available to us. Recent publications of Pteris in adjacent regions, especially the checklist of Pteris of Nepal (Fraser-Jenkins et al., 2015) and that of India (Fraser-Jenkins et al., 2017), are also consulted. Our recently collected specimens in Sylhet were deposited in Herbarium of South China Botanical Garden, Chinese Academy of Sciences (IBSC).

\section{Result and Discussion}

We recognize 15 species of Pteris from Bangladesh for the time being. Of the 15 species, $P$. giasii is currently only known in Bangladesh and P. longipinnula has not been collected or reported in Bangladesh since 1858. An updated taxonomic checklist including a key to the species of Pteris of Bangladesh is provided below.

\section{Key to species of Pteris in Bangladesh}

1a. Lateral pinnae pectinate, i.e., regularly deeply lobed on both sides of costae (rarely lobed only on basiscopic side)

1b. Lateral pinnae simple (not lobed), or at most with one to three lobes on one or both sides of costae

2a. Pinnae 1-pinnate-pinnatifid, at least lowest pinnae with several pairs of pectinate pinnules

10. P. khasiana

2b. Pinnae pinnatifid, or at most the lower ones having one to three basiscopic branches

3a. Fronds pentagonal; lateral pinnae 1-2 pairs, their bases connected with rachis-wings

8. P. grevilleana

3b. Fronds oblong to lanceolate; lateral pinnae more than 3 pairs; rachis wingless 
4a. Lateral pinnae pectinate only on basiscopic side of costae

13. P. semipinnata

4b. Lateral pinnae symmetrically pectinate on both sides of costae

5a. Veins anastomosing below sinuses between pinna-lobes, forming costal areoles

5b. Veins all free (or those below sinuses occasionally anastomosing), not forming costal areoles

6a. Pinna-lobes entire at margin

6b. Pinna-lobes with the distal sterile parts obviously crenate

7a. Lowest pinnae not forked, without branches on basal basiscopic side

2. P. biaurita

6. P. geminata

7b. Lowest pinnae forked, each with one or two short branches on basal basiscopicside

8a. Frond-axes bright blueish-green; pinna-lobes mucronate at apex

11. P. longipinnula

8b. Frond-axes stramineous or brown; pinna-lobes acute, never mucronate at apex

7. P. giasii

9a. Fronds herbaceous; costae without spines on the adaxial surface

1. P. assamica

9b. Fronds chartaceous; costae obviously with spines on adaxial surfaces

10a. Pinnae cordate at base; lower pinnae gradually reduced in length

3. P. blumeana

10b. Pinnae cuneate at base; lower pinnae not reduced

15. P. vittata

11a. Sterile segments entire at margin

11b. Sterile segments serrate at margin

12a. Fronds 1-pinnate and becoming 2-pinnate towards base; ultimate segments linear, mostly $1.5-3 \mathrm{~cm}$ long

12b. Fronds uniformly 1-pinnate; pinnae much longer, 15-20(30) $\mathrm{cm}$ long

13a. Fronds 1-pinnate to 2-pinnate towards base; lateral pinna 3-5 pairs; rachis wingless

9. P. griffithii

14. P. venusta

5. P. ensiformis

13b. Fronds simple, digitate, or consisting of a trilobed terminal part and a pair of lateral segments or pinnae; rachis usually winged

14a. Fronds digitate to 1-pinnate, segments or pinnae irregularly lobed, producing one to several lobes on one or both sides of costae

4. P. cadieri

14b. Fronds simple, or digitate, if digitate or nearly pinnate, the segments linear and simple (never lobed)

12. P. pseudopellucida

1. Pteris assamica Fraser-Jenk. \& T.G. Walker, Taxon. Revis. Indian Subcontinental Pteridophytes 118. 2008. - Type: INDIA. Assam: Bor Bhil marsh, near Digboi, 27 Dec 1995, C.R. Fraser-Jenkins 23943 "F.N. Pt. 84" (holotype, BM, not seen).

Pteris assamica is morphologically similar to $P$. biaurita but differs in its veins being wholly free (versus forming costal areoles), lamina herbaceous (versus chartaceous) in texture, costae spines lacking (versus present), and the basal basiscopic segments on lowest pinnae usually being asymmetric (versus symmetric) (i.e., long and simple on one of the lowest pair of pinnae whereas normal-sized and pinnatifid on the other in P. assamica, Fraser-Jenkins, 2008: 118).

In Bangladesh, it is known from Chittagong (C.R. Fraser-Jenkins 31011, TAIF). The species was also reported from India, Bhutan, Malaysia, Myanmar, Nepal, and Thailand (Fraser-Jenkins et al., 2017). 
2. Pteris biaurita L., Sp. Pl. 2: 1076. 1753; Siddiqui et al., Encycl. Flora Fauna Bangladesh 5: 236. 2007.-Type: "Domingo, Martinica, Jamaica", Anonymous s.n. (lectotype, LINN1246.19, designated by Tryon in Contr. Gray Herb. 194: 201. 1964).

Fraser-Jenkins et al. (2015) recognized two subspecies of Pteris biaurita, namely subsp. fornicata Fraser-Jenk. and subsp. walkeriana Fraser-Jenk. \& Dominic Rajkumar. It seems difficult and unpractical to accept the two subspecies under P. biaurita, since "the subsp. walkeriana is very similar to and slightly overlaps subsp. fornicata" (Fraser-Jenkins et al., 2015: 319). In addition, one voucher specimen from Chittagong (King's collector 185, US-01480252) morphologically matches well with the type of $P$. biaurita. Therefore, we propose to maintain using only P. biaurita for plants in Bangladesh.

In Bangladesh, it is known from Chittagong (P.F. Lu et al. 16173, TAIF). This species is widespread in pantropical areas.

3. Pteris blumeana J. Agardh, Recens. Spec. Pter. 22. 1839. - Pteris quadriaurita Retz. var. blumeana C.B. Clarke, Trans. Linn. Soc. London, Bot. 1: 466, pl. 55. 1880; Siddiqui et al., Encycl. Flora Fauna Bangladesh 5: 243. 2007. -Type: INDONESIA. Java, in 1836, M. Blume s.n. (syntype, B-20 0033826).

Pteris quadriaurita var. setigera auct., non Bedd., Siddiqui et al., Encycl. Flora Fauna Bangladesh 5: 244. 2007.

When originally describing Pteris blumeana, Agardh (1839: 23) cited Blume's collection from Java as the voucher and mentioned its distribution also in India Orientale. To locate the type specimens of this species, we so far traced only a sheet containing pinna fragments of Blume's collection in B (barcoded B 20 0033826), which should be considered as a syntype of $P$. blumeana.

Pteris blumeana is very similar to P. biaurita in appearance but differs mainly in its free veins, i.e., the lowest veins of pinna-lobes reaching lamina margin above sinuses, never anastomosing (versus veins forming narrow areoles along pinna-costae in P. biaurita).

In Bangladesh, it is known from Chittagong (Clarke, 1880: 466). This species is distributed also in Cambodia, India, Indonesia, Laos, Myanmar, Singapore, Thailand, Vietnam (Lindsay and Middleton, 2012; Fraser-Jenkins et al., 2017).

4. Pteris cadieri Christ, J. Bot. (Morot) 19: 72. 1905. —Type: VIETNAM. Quang Binh: "SongGianh" Valley, in 1903, L. Cadiere 86 (holotype, P-00532183; isotypes: BM-001044188, P00532184).

Pteris plumbea Christ, Notul. Syst. (Paris) 1: 49. 1909; Siddiqui et al., Encycl. Flora Fauna Bangladesh 5: 241. 2007. - Type: CHINA. Guangdong: Shantou (formerly as Swatou), Asverus \& Henry s.n. (lectotype, P-00538980, designated here).

The irregular dissection of lamina indicates the hybrid origin of Pteris cadieri. According to Chao et al. (2015), P. plumbea should be treated as a synonym of $P$. cadieri which is a complex involving complicated hybridization. When Christ (1909) firstly described $P$. plumbea, he cited three specimens from different localities, one from China and other two from Philippines; all the three are syntypes according to ICN (Turland et al., 2018; Art. 9.5,). One of them, Asverus \& Henry s. $n$. in herbarium $\mathrm{P}$, is here designated as the lectotype of $P$. plumbea.

In Bangladesh, it was reported from Rangamati District (Mirza \& Rahman, 1997). The species is distributed also in China, Philippines, Thailand, and Vietnam (Chao et al., 2015). 
5. Pteris ensiformis Burm. f., Fl. Indica. 230. 1768; Siddiqui et al., Encycl. Flora Fauna Bangladesh 5: 237. 2007. -Type: SRILAN KA. Anonymous s.n. (lectotype, G-00360109, designated by Fraser-Jenkins et al. in Annot. Checkl. Indian Pterid. 1: 286. 2017).

It is a distinct species characterized by its dimorphic fronds, pinnae in fertile fronds being linear and almost each pinna bearing a short segment on basal basiscopic side, and those in sterile fronds much shorter and wider, their bases with one or two pairs of pinnules.

In Bangladesh, it is known from Chittagong (P.F. Lu et al. 16184 \& 16185, TAIF) and Moulvibazar (Kamrul 1985, JUH; M.A. Rahim 2482, JUH). The species is widespread in tropical Asia, southeast to Australia and Polynesia (Fraser-Jenkins et al., 2015).

6. Pteris geminata Wall. ex J. Agardh, Recens. Spec. Pter. 31. 1839. -Pteris geminata Wall. ex Tardieu, Fl. Madagasc. 5: 101. 1958, later homonym. - Type: INDIA. Tamil Nadu, herb. $R$. Wight s.n. (N. Wallich Cat. no. 2180) (holotype, K-001057861).

Siddiqui et al. (2007: 238) recorded Pteris geminata Wall. ex Hook. in Bangladesh and indicated the name is from Hooker's Species Filicum on the page "1: 53 (1846)". However, there is no such a name in Hooker's Species Filicum. So far as we know, it is Agardh (1839: 31) who firstly validly published Wallich's Pteris geminata. Thus, the authorship of Pteris geminata should be written as "Wall. ex J. Agardh". Its type (i.e., Wallich Cat. no. 2180 at K) morphologically resembles $P$. biaurita but differs in its pinna-lobes being acuminate and serrate towards apexes (versus round and entire).

The natural distribution of $P$. geminata in Bangladesh is to be confirmed. In Bangladesh, it was reported from Chittagong (Mirza and Rahman, 1997). But according to Fraser-Jenkins et al. (2017), this species is distributed only in South India and Comoro Islands.

7. Pteris giasii Fraser-Jenk. \& Pasha, Taxon. Revis. Indian Subcontinental Pteridophytes 119. 2008. - Type: BANGLADESH. Chittagong: Chittagong Hill Tracts, C.R. Fraser-Jenkins 30176 (holotype, BM, not seen; isotype, TAIF-358100).

It appears to be a distinct species characterized by its 1-pinnate-pectinate fronds, free veins, and lowest pinnae always being simple (never forked). Pteris giasii somewhat resembles $P$. longipinnula Wall. ex J. Agardh but differs in its stramineous to brown color frond-axes (stipe, rachis, and costa), pinnae bases broadened, and apexes of pinna-lobes acute and not mucronate. In comparison, $P$. longipinnula has frond-axes being bright blueish-green, pinnae bases usually apparently narrowed, and apexes of pinna-lobes being round and mucronate.

It is currently known to be endemic to Bangladesh (Chittagong Hill Tracts) (C.R. FraserJenkins 30177, TAIF).

8. Pteris grevilleana Wall. ex J. Agardh, Recens. Spec. Pter. 23. 1839; Siddiqui et al., Encycl. Flora Fauna Bangladesh 5: 239. 2007. - Type: BANGLADESH. Sylhet, W. Gomez s.n. (N. Wallich Cat. no. 2680) (holotype, K-000442839; isotypes: B-20 0139511, E-00257673).

A species characterized by its digitate fronds, lateral pinnae only 1-2 pairs, and the presence of false veins between true veins.

In Bangladesh, it is known from Sylhet (type locality). This species is distributed also in China, India, Myanmar, Singapore, Thailand, and Vietnam (Fraser-Jenkins et al., 2017).

9. Pteris griffithii Hook., Sp. Fil. 2: 170, t. 123A. 1858; Siddiqui et al., Encycl. Flora Fauna Bangladesh 5: 239. 2007. -Type: INDIA. Mishmee, W. Griffith s.n. (holotype, K001057864). 
A special species characterized by its elongate-triangular lamina, lower lamina being remarkably broadened and 2-pinnate, and all ultimate segments widely spaced.

In Bangladesh, it is known from Moulvibazar (Kamrul 1976, JUH). The species is distributed also in India, Bhutan, and Myanmar (Fraser-Jenkins et al., 2017).

10. Pteris khasiana (C.B. Clarke) Hieron., Hedwigia 55: 364. 1914. -Pteris quadriaurita var. khasiana C.B. Clarke, Trans. Linn. Soc. London, Bot. 1: 466, pl. 53. 1880; Siddiqui et al., Encycl. Flora Fauna Bangladesh 5: 243. 2007.-Type: BANGLADESH. "E Sylhet, misit $F r$. De Silva, in 1821", N. Wallich Cat. no. 106.5 (lectotype, designated by Fraser-Jenkins \& Matsumoto in 2015, K, not seen).

A species with completely 2-pinnate fronds, strikingly different from other pinna-pectinate species by its pinnae being 1-pinnate-pectinate (versus uniformly pectinate, sometimes with one or two pectinate segments on lowest pinnae).

In Bangladesh, it is known from Sylhet (locality of the lectotype). This species is distributed also in Bhutan, China, India, Myanmar, and Nepal (Fraser-Jenkins et al., 2017).

11. Pteris longipinnula Wall. ex J. Agardh, Recens. Spec. Pter. 19. 1839. -Type: MALAYSIA. Penang, N. Wallich Cat. no. 108 (holotype, B-20 0127560).

(Fig. 1).

It is a very distinct species with pectinate pinnae. This species is morphologically similar to Pteris biaurita but differs in its stipe, rachis and costa being bright blueish-green in color (versus stramineous), lowest pinnae lacking produced basal basiscopic pinnules, pinnae deeply lobed to or nearly to the costae (versus lobed to wide costa-wing), and lowest veins of lobes free and spreading to segment edge above sinuses (versus anastomosing below sinuses).

Pteris longipinnula was reported in wide range of Asia, from NE India, Myanmar and China, south to Indonesia and southeast to Philippines (Fraser-Jenkins et al., 2015), but was not included in Encyclopedia of Ferns and Fauna of Bangladesh (Siddiqui et al., 2007). When sorting out literature on Pteris from Bangladesh, we found that P. longipinnula had been collected by J.D. Hooker and T. Thomson from Sylhet probably in 1850s (Hooker, 1858). Since then this species has never been collected or reported in Bangladesh. Till September 2019 when surveying ferns in Sylhet, we found this species (S.Y. Dong 5190, IBSC) in rain forest of Khadimnagar National Park.

12. Pteris pseudopellucida Ching, Lingnan Sci. J. 15: 395. 1936; Siddiqui et al., Encycl. Flora Fauna Bangladesh 5: 241. 2007. - Type: INDIA. Khasia, W. Griffith s.n. (holotype, K001057865).

A species with variable fronds, ranging from simple, trilobed, to 1-pinnate (i.e., fronds consisting of a trilobed terminal part and a pair of lateral linear pinnae which adjoin to rachis-wing at base).

In Bangladesh, it is known from Moulvibazar (Kamrul 1940, 1941 \& 1942, JUH). This species is distributed also in China, India, Laos, Myanmar, and Vietnam (Fraser-Jenkins et al., 2017).

13. Pteris semipinnata L., Sp. Pl. 2: 1076. 1753, nom. cons. -Type: CHINA. Guangdong: Guangzhou, Gröndal s.n. (conserved type, S-P-5847).

Pteris semipinnata is unique from other Pteris species from Bangladesh by its "semi-pinnate" pinnae, namely, pinnae being pectinate only at basiscopic side of costae. 
In Bangladesh, it is known from Chittagong (P.F. Lu et al. 16231, TAIF) and Moulvibazar (Kamrul 1979 \& 1980, JUH). This species is widespread throughout SE Asia, northwest to NE India, and naturalized in N Australia (Fraser-Jenkins, 2008).

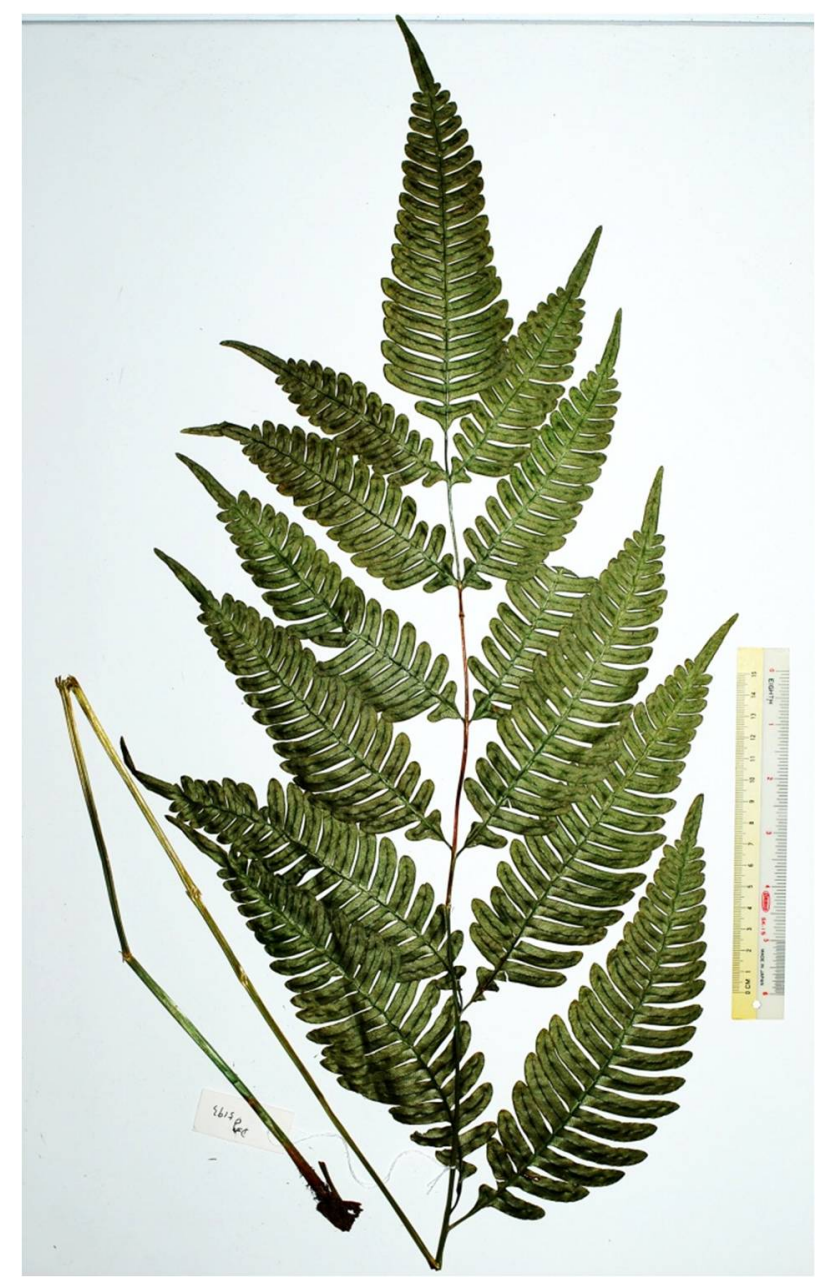

Fig. 1. The collection of Pteris longipinnula Wall. ex J. Agardh newly found in Sylhet (S.Y. Dong 5193, IBSC).

14. Pteris venusta Kunze, Bot. Zeitung (Berling) 6: 195. 1848; Siddiqui et al., Encycl. Flora Fauna Bangladesh 5: 245. 2007. - Type: INDONESIA. Java, H. Zollinger 918z (holotype, B$200127565)$.

Pteris pellucida auct., non C. Presl, Siddiqui et al., Encycl. Flora Fauna Bangladesh 5: 240. 2007.

A species characterized by its 1-pinnate fronds and linear, entire pinnae.

Fraser-Jenkins et al. (2015) proposed to recognize a separate subspecies, namely Pteris venusta subsp. matsudae (Masam.) Fraser-Jenk. \& Kandel, from subsp. venusta. We don't think 
they made clear the difference of morphology and geographic distribution between the two subspecies. As the concept of $P$. venusta subsp. matsudae sensu Fraser-Jenkins et al. (2015) is obscure, we tentatively use only $P$. venusta for the plants in Bangladesh.

In Bangladesh, it is known from Chittagong (J.L. Lister s.n., US; P.F. Lu et al. 16165 \& 16211, TAIF) and Moulvibazar (Kamrul 1977 \& 1978, JUH; M.A. Rahim 2487, JUH). The species is widespread in S \& SE Asia.

15. Pteris vittata L., Sp. Pl. 2: 1074. 1753. - Type: CHINA. Guangdong: Guangzhou, in 1751, P. Osbeck s.n. (lectotype, LINN-1246.3, designated by Tryon in Contr. Gray Herb. 194: 191. 1964).

A species with some unique characters, such as fronds being oblanceolate in shape, pinnae numerous (usually 15-35 pairs) and linear in shape with cordate bases, and when young its stipe and rachis bearing copious spreading hairs.

Pteris longifolia var. vittata Roxb. was recorded by Siddiqui et al. (2007: 240) as a taxon in Bangladesh flora. However, it seems that there is no such a name in science. According to the description of "Pteris longifolia var. vittata" given by Siddiqui et al. (2007: 240), the taxon should be named Pteris vittata.

In Bangladesh, it is known from Chittagong (J.L. Lister s.n., US; P.F. Lu et al. 16213 \& 16219, TAIF) and Moulvibazar (Kamrul 1975, JUH; M.A. Rahim 2485, JUH). The species is widespread in tropics and subtopics of the Old World.

\section{Excluded species:}

1. Pteris cretica L., Mant. Pl. 130. 1767; Siddiqui et al., Encycl. Flora Fauna Bangladesh 5: 237. 2007. -Type: "Habitat in Creta, Ilva Insula", Arduino s.n. (lectotype, LINN-1246.7, designated by Tryon in Contr. Gray Herb. 194: 192. 1964).

In Bangladesh, this species has not been found in wild. Siddiqui et al. (2007) included this species in Encyclopedia Flora and Fauna of Bangladesh just because it was used as ornamental plants in Bangladesh.

2. Pteris pellucida C. Presl, Reliq. Haenk. 1: 55. 1825.-Type: PHIPPINES: Luzon, T.P.X. Haenke 118 (holotype, PRC-450304).

According to Fraser-Jenkins et al. (2017), Pteris pellucida is a Philippine species and has not found in Indian subcontinent. The record of plants from Indian subcontinent formerly called as $P$. pellucida is probably due to misidentification of either $P$. pseudopellucida, a species characterized by sterile segments being finely serrate at margin, or $P$. venusta with entire pinna-segments.

3. Pteris quadriaurita Retz. Observ. Bot. 6: 38. 1791. - Type: SRI LANKA. Without locality, König s.n. (holotype, LD-1221924).

According to Walker (1960), the name Pteris quadriaurita has been wrongly applied to various species and the true $P$. quadriaurita is distributed only in Sri Lanka and South India. The recognition of $P$. quadriaurita in Bangladesh (Siddiqui et al., 2007) is probably due to misidentification.

4. Pteris tenuissima Ching, Lingnan Sc. J. 15: 394. 1936. -Pteris quadriaurita var. setigera Bedd., Ferns Brit. Ind., t. 202. 1866. - Pteris setigera (Bedd.) N.C. Nair, Bull. Bot. Surv. India 11: 187. 1971.-Type: MYANMAR. Moulmein, on limestone rocks, Parish s.n. (lectotype, designated here, K-001057845; isolectotypes: K-001057846, K-001057847, BM001044181). 
According to Fraser-Jenkins et al. (2017), Pteris tenuissima Ching is endemic to Myanmar; however, Beddome (1876) misapplied P. quadriaurita var. setigera (= P. tenuissima) for the plants from South India. The P. quadriaurita var. setigera sensu Siddiqui et al. (2007) is a wrong report of $P$. blumeana.

\section{Acknowledgements}

We thank the curator and staff of herbaria JUH (Herbarium of Jahangirnagar University) and TAIF (Herbarium of Taiwan Forestry Research Institute) for allowing access to their collections. M.S. Rahman and M.A. Rahim assisted the field work in Bangladesh. Cheng-Wei Chen helped to check some specimens of Pteris from Bangladesh in TAIF. This study was supported by National Natural Science Foundation of China (grant no. 31970218).

\section{References}

Agardh, J.G. 1839. Recensio Specierum Generis Pteridis. Typis Berlingianis, Lundae, pp. 1-86.

Beddome, R.H. 1876. Supplement to the ferns of southern India and British India. Madras: Adelphi Press, Madras, pp. 1-28.

Chao, Y.S., Liu, H.Y. and Chiou, W.L. 2015. Taxonomic revision of the Pteris cadieri complex (Pteridaceae). Phytotaxa 230: 130-150.

Ching, R.C. and Wu, S.H. 1983. Materials for the Pteris flora of China. Acta Bot. Austro Sin. 1: 1-16.

Christ, H. 1909. Filices novae Chinenses. Notul. Syst. (Paris) 1: 33-59.

Christensen, C. 1906. Index Filicum. H. Hagerup, Copenhagen, pp.1-744.

Clarke, C.B. 1880. A revision of the ferns of northern India. Trans. Linn. Soc. London, Bot. 1: 425-611.

Fraser-Jenkins, C.R. 2008. Taxonomic Revision of Three Hundred Indian Subcontinental Pteridophytes with a Revised Census-list. Bishen Singh Mahendra Pal Singh, Dehra Dun, pp. 1-685.

Fraser-Jenkins, C.R., Gandhi, K.N., Kholia, B.S. and Benniamin, A. 2017. An Annotated Checklist of Indian Pteridophytes, part 1. Bishen Singh Mahendra Pal Singh, Dehra Dun, pp. 1-562.

Fraser-Jenkins, C.R., Kandel, D.R. and Pariyar, S. 2015. Ferns and Fern-allies of Nepal, vol.1. National Herbarium and Plant Loboratories, Kathmandu, pp. 1-492.

Hooker, W.J. 1858. Species Filicum, vol. 2. W. Pamplin, London, pp. 1-250.

Kamau, P.W. 2012. Systematic revision of Pteris L. in tropical Africa and ecology of ferns and lycophytes in lowland tropical rainforests. Doctoral dissertation of Universität Koblenz-Landau, Mainz, Germany, pp. $1-173$.

Kramer, K.U. and McCarthy, P.M. 1998. Pteridaceae. In: McCarthy, P.M. (Ed.), Flora of Australia 48: 241248.

Liao, W.B., Ding, M.Y., Wu, Z.H., Prado, J. and Gilbert, M.G. 2013. Pteris. In: Wu, Z.Y., Raven, P.H. and Hong, D.Y. (Eds.), Flora of China, vol. 2-3. Science Press, Beijing; Missouri Botanical Garden Press, St. Louis, pp. 181-211.

Lindsay, S. and Middleton, D.J. 2012. Ferns of Thailand, Laos and Cambodia. http://rbgweb2.rbge.org.uk/thaiferns/

Mirza, M.M. and Rahman, M.M. 1997. An annotated checklist of ferns and fernallies of Bangladesh. Bangladesh J. Plant Taxon. 4: 47-69.

Nakaike, K. 1982. New Flora of Japan Pteridophyta. Shibundo Co., LTD. Publishers, Tokyo, pp. 1-808.

Phan, K.L. 2010.The updated checklist of the fern flora of Vietnam following the classification scheme of A. Smith et al. (2006). J. Fairylake Bot. Gard. 9: 1-13.

PPG I. 2016. A community-derived classification for extant lycophytes and ferns. J. Syst. Evol. 54: 563-603. 
Siddiqui, K.U., Islam, M.A., Ahmed, Z.U., Begum, Z.N.T., Hassan, M.A., Khondker, M., Rahman, M.M., Kabir, S.M.H., Ahmad, M., Ahmed, A.T.A., Rahman, A.K.A. and Haque, E.U. (Eds.). 2007. Encyclopedia of Flora and Fauna of Bangladesh, Vol. 5. Bryophytes, Pteridophytes, Gymnosperms. Asiatic Society of Bangladesh, Dhaka, pp. 1-391.

Tryon, R.M., Tryon, A.F. and Kramer, K.U. 1990. Pteridaceae. In: Kramer, K.U. and Green, P.S. (Eds.), the Families and Genera of Vascular Plants, vol. 1. Pteridophytes and Gymnosperms. Springer-Verlag, Berlin, pp. 230-256.

Tryon, R.M. and Tryon, A.F. 1982. Ferns and Allied Plants with Special Reference to Tropical America. Springer-Verlag, New York, pp. 332-338.

Turland, N.J., Wiersema, J.H., Barrie, F.R., Greuter, W., Hawksworth, D.L., Herendeen, P.S., Knapp, S., Kusber, W.H., Li, D.Z., Marhold, K., May, T.W., McNeill, J., Monro, A.M., Prado, J., Price, M.J. and Smith, G.F. (Eds.). 2018. International Code of Nomenclature for algae, fungi, and plants (Shenzhen Code) adopted by the Nineteenth International Botanical Congress Shenzhen, China, July 2017. Koeltz Botanical Books, Glashütten.

Walker, T.G. 1960. The Pteris quadriaurita complex in Ceylon. Kew Bull. 14: 321-332.

Zhang, L., Rothfels, C.J., Ebihara, A., Schuettpelz, E., Pechon, T.L., Kamau, P., He, H., Zhou, X.M., Prado, J., Field, A., Yatskievych, G., Gao, X.F. and Zhang, L.B. 2014. A global plastid phylogeny of the brake fern genus Pteris (Pteridaceae) and related genera in the Pteridoideae. Cladistics 2014: 1-18.

(Manuscript received on 19 July, 2020; revised on 12 April, 2021) 